\title{
Energy Management of Stand-alone Hybrid Generation System
}

\author{
B. Deepika ${ }^{1}$ and Dr. R. Vijay ${ }^{2}$ \\ ${ }^{1}$ PG Scholar, CVR College of Engineering/EEE Department, Hyderabad, India \\ Email: deepukondru93@gmail.com \\ ${ }^{2}$ Assoc. Professor, CVR College of Engineering/EEE Department, Hyderabad, India \\ Email: vijai.mtp@gmail.com
}

\begin{abstract}
This paper offers a distinct self-power composite electricity production system, which employs modern energy management methods. The energy sources such as wind farms and solar energy with battery, and diesel combustion engine alternator or fuel cell are considered for energy management, which is isolated from the trade power system. Substantial effort is laid towards the growth of real-reactive power and collapses energy management. The magnitudes and phase angles of the alternating output voltage are well-supervised in the designed composite system. In this composite power system, various energy sources are coupled at all locations on the same supply line. This results in a power system generation growth towards the standard. Furthermore, this will progress world energy security in distant regions and agricultural zones with independence on marketable power systems.
\end{abstract}

Index Terms: standalone power system, diversion power control, hybrid wind-solar power, self-power composite electricity production system, storage battery, fuel cell.

\section{INTRODUCTION}

With the rapid rise in energy demand and rising concerns towards the environmental impact due to the high degree of reliability on fossil fuels, renewable power production and clean power techniques play a crucial role in the future tolerable power system. The dispersed non-conventional power systems and small-production systems such as solar photovoltaic array (PVA) and wind farms are offered to reduce power demand from the utility grid. Since nonconventional energies are from the organic environment, it is dependent on all seasons which make them insecure when one renewable source is applied to build a constant power system. Using a combination of multiple renewable sources such as solar and wind supplementing each other, where sunlight is available over the day, and wind energy at night in winter and summer seasons.

The combination of variable renewable resources is allowed for soft, steady, and authentic output to power grids aimed at the protection, consistency, and constancy of dispatch power, which is cheaper than investing in single non-conventional technology [1]. Recently, eco-friendly solutions are gaining importance for energy generation to overcome environmental problems, but uncertainty in nature is the main constraints of non-conventional sources to produce uninterrupted power. To overcome these disadvantages, different renewable sources such as solar PVA, wind farm, and battery are to be included. The biggest challenge of this incorporation is to control and handle the power flow [2]. The best design and performance of a connectionless PVA/fuel cell/diesel alternator energy system has been explained as follows.

The main objective is to propose an energy system with a high non-conventional fraction; low greenhouse gas discharges, and less cost of energy. The goal is to control from grid-connected fossil fuel energy system to a non-conventional and good power system [3]. Stand-alone photovoltaic (PV) systems are mostly used to produce electrical energy in agricultural areas. Migrants in PV radiation influence electrical energy produced by solar stand-alone PV systems. The PV systems strictly need energy-saving units like batteries to balance the solar energy deficiency. The batteries can store electric strength with an excessive-electricity ratio; however, their potential is constrained. Supercapacitors have a high energy density with a low-electricity density. A combination of each power storage gadget is required to be related in a suitable configuration, that it caters to the power call for and strength exceptional concerns of the sun stand-alone PV systems [4]. A Hybrid Power Storage Device (HPSD) is a promising solution for mitigating these strength fluctuations. The electricity that the HPSD additives have to deliver/absorb, the Electricity Control Method (ECM) impacts the dimensions/capacity of the Energy storage system.

Based on this consideration, sizing and ECM of a battery/supercapacitor (SC) HPSD is mutually optimized employing the use of a deep reinforcement mastering-based totally technique. The proposed technique splits the electricity between the HPSD additives so that the operational constraints are rectified. Correspondingly the electricity garage length and losses are minimized [5-6]. A techno-economic evaluation based totally on incorporating modeling, simulation, and optimization techniques is used to layout an off-grid hybrid sun PV/fuel cell power device. The major objective is to optimize the design and broaden dispatch, manage techniques of the standalone hybrid renewable electricity device to satisfy the desired electric powered load of a residential community positioned in a desert.

The results of temperature and dirt accumulation at the sun PV panels in the design and overall performance of the hybrid power machine in a wasteland location are investigated. The intention of the proposed off-grid hybrid renewable electricity system is to increase the penetration of renewable power in the power mix. Lesser the greenhouse fuel emissions from fossil gasoline combustion, and decrease the cost of power from the power structures. Simulation, modeling, optimization, and dispatch, manage 
techniques were used to determine the overall performance and the cost of the proposed hybrid renewable strength machine [7].

The feasibility and ideal sizing layout of a stand-on wind/hydrogen hybrid power machine for a residence are taken into account with no connection to the electricity grid lines. The designed device ensures uninterrupted, reliable, continuous electricity to the residence at any time. The wind strength, and the considered hybrid PV-wind and the fuel cell system is a good alternative for providing the power $[8,9]$. Off-grid packages (i.e., users not connected to a country's primary electric grid) are assuming an increasing number of essential functions inside the future energy structures $[9,10]$.

In contrast, almost the complete transportation region (excluding trains) may be considered as made of off-grid $[11,12]$ structures (e.g., vehicles, trucks, planes, and ships). More typically, numerous elements contribute to a renewed interest in small-scale technology. Among them are the price and public opposition to new transmission lines and large power vegetation $[13,14]$. The need of reducing the vulnerability of the supply chain in centralized structures, and the elevated overall performance of small electricity technologies $[15,16]$. Hybrid renewable electric powered energy era devices emerge as crucial to most electrical networks and the stand-alone systems like the water pumping and telecommunication systems. Renewable resources generally required garage devices due to change in the electrical outputs in the day.

Due to an increase in the demand for the use of batteries, the charging procedure of battery gadgets needed to be properly controlled through an adaptive managed power handling machine. Fuel Cell (FC) strength plants are electrochemical devices that convert the chemical strength of a reaction directly into electricity. It generates power through an electrolytic reaction, not combustion. In a fuel cell, hydrogen and oxygen are used to generate electricity, heat, and water. Fuel cells are used nowadays in a range of applications, to provide power to homes and businesses, and for supply power to critical facilities like hospitals, supermarkets, and computer centre. These are used to move a variety of vehicles includes cars, buses, goods vehicles, excavators, trains, and more.

This paper deals with the different kinds of energy resources such as solar PVA and wind farms. As well as storage batteries, and diesel generator, or fuel cell with different types of control techniques to contribute and manage the power in off-grid. The remaining of this paper is outlined as follows: Section II describes the prototype of the hybrid system. Section III is about energy monitoring methods. The modeling and simulation results are shown in Section IV. Conclusions are presented in Section V.

\section{HYBRID ENERGY SYSTEM}

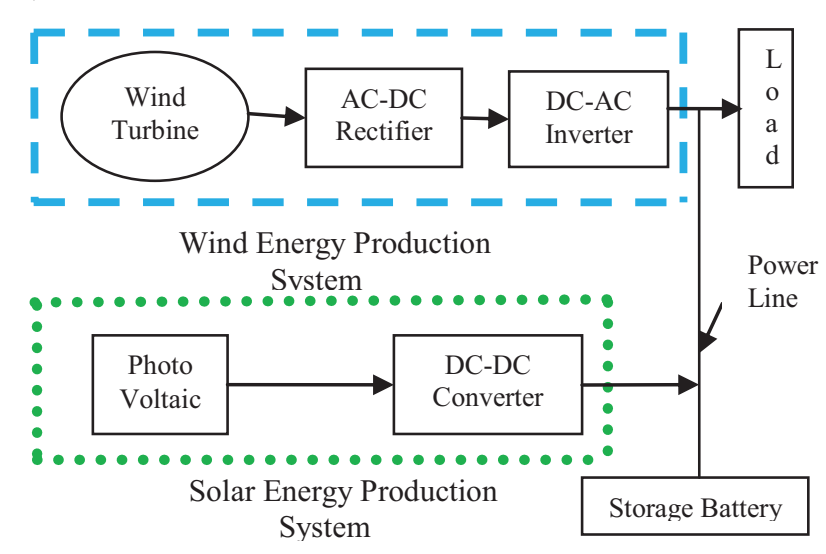

Figure 1. Hybrid energy system without backup devices.

The wind and solar systems are needed to supply the power to the load and are shown in Fig.1. But if they fail to meet the load demand, then the backup devices, i.e., storage battery and diesel generator/fuel cell are needed to supply the power to the load.

\section{A. Hybrid System Configuration:}

The hybrid system consists of the following characteristics.

1) The various energy sources are interlinked in parallel.

2) Removal of diversion load by using an individual diversion energy control focused on avoiding battery excess charging.

3) A high-speed line is unnecessary for battery modernday/voltage report data communication.

4) Extension of capacity is easy through a parallel connection of extra power sources to cope with future load growth.

Particular concentration has also been given to PhaseLocked Loop (PLL) control methods via workshop tests, and examines the performance of the current/voltage effect of input real-reactive energy parameters into an energy control network test and established suitable energy to manage the result. The proposed self-power composite electricity production system is, as shown in Fig.2. 


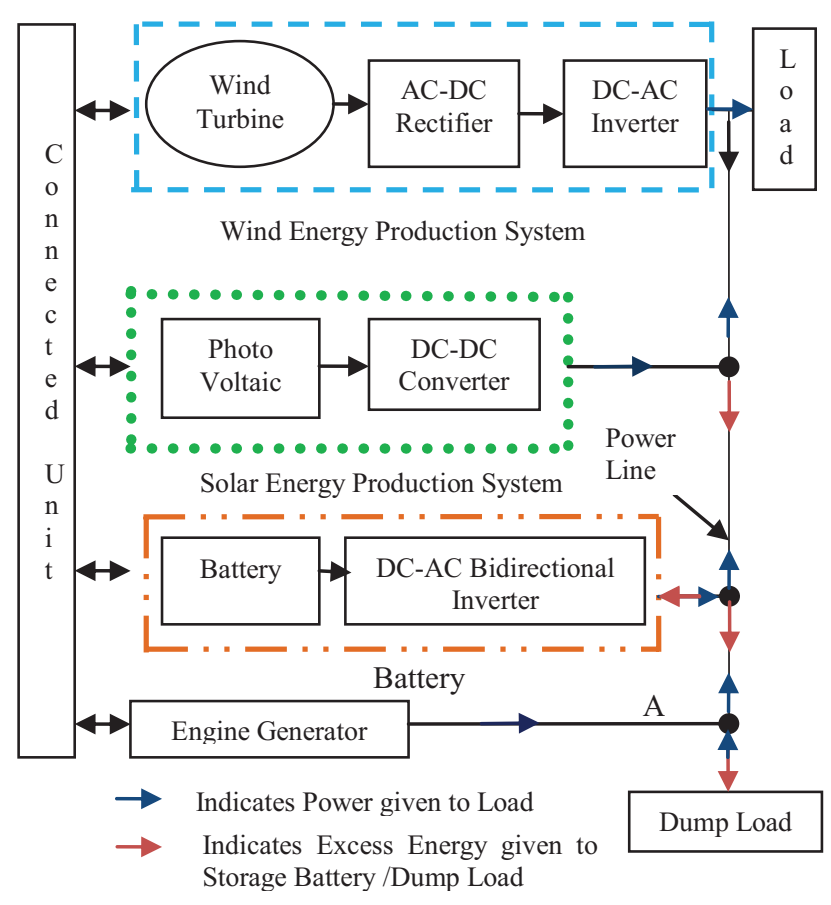

Figure 2. Hybrid energy system with backup devices.

\section{B. Hybrid System Operation:}

Major operation flows of the planned hybrid system are explained below.

1) When the leftover battery potential is satisfactory: Engine Generator (EG) action stops, and all inverters operate in parallel. Energy excess and shortage, according to the equilibrium among the output and load are optimally used via battery charging or discharging.

\section{2) When the leftover battery potential is unsatisfactory:}

EG and all inverters work in parallel. When the energy produced by wind and PV energy production systems is inadequate to reach load demand, EG balance for the shortage. Simultaneously, EG charges the battery through the two way inverter. This inverter improves charging energy for the battery so that EG operated at the better load factor matches with high efficiency and the following command from the monitoring unit.

\section{Hybrid ENERgy System Monitoring Methods}

In the proposed composite system, it focused on monitor real-reactive energy on load distribution in parallel inverter operations and phase management. Through further study energy diversion control method is considered without a diversion load.

\section{A. Real-Reactive Energy Balance}

The auto-master-slave control technique is applied in all inverters. When EG is in operation, the switch of each inverter is closed, and these switches are in ACsynchronized operation with all inverters that operate as slaves and with EG as the master. When EG operation stops, the switch of the battery bank two-way inverter is closed. This inverter works as a master and is under the Constant Voltage Constant Frequency (CVCF) condition. The switch of each remaining inverter that acts as a slave is closed which is shown in Fig.3. Then, the AC-synchronized operation is undergone. The proposed composite system concentrates on the method of the PLL in the real-reactive energy control.

\section{1) Parallel Inverters Operation:}

In this assembly a sample self-power composite electricity production system, and conducted experiments.

$X_{1}, X_{2}$ and $X_{3}$ are interlinked reactors arranged in WT inverter, PV inverter, and two-directional inverters respectively. This research finds the optimal real reactive energy parameters for each inverter to improve the output under the conditions that each inverter capacity is $3 \mathrm{kVA}$ (with a power factor of 0.8 ) and the output voltage is singlephase $100 \mathrm{~V}, 60 \mathrm{~Hz}$.

\section{2) Phase-Locked Loop/Feedback Control Loop:}

The PLL, which acts as a phase synchronization control, is consists of a phase comparator, low-pass (LP) filter, phase shifter, multiplier, and Voltage-Controlled Oscillator (VCO). The phase comparator acts to expand the AC output voltage wave by the cosine wave pass on hence obtained from the sine wave reference passes through the phase shifter. The expanded wave is changed to DC voltage for VCO frequency control through the LP filter.

PLL consists of two control elements, the phase comparator output, and the phase reference signal which is introduced into the LP filter and shown in Fig.4. The phase comparator output is introduced as synchronization data (i.e., the difference compared to reference frequency). The phase reference signal is introduced as the amount of phase shift in inverter output voltage at the same time by balancing the synchronization in opposition to voltage in the marketable energy system. Thus, the real power changes along with the change in the phase Reference signal.

\section{3) Parallel Inverters Operation:}

In this construction a sample self-power composite electricity production system and conducted laboratory experiments. $X_{1}, X_{2} \& X_{3}$ are interlinked reactors arranged in WT inverter, PV inverter, and two-directional inverters respectively. The research finds the optimal real reactive energy parameters for each inverter to improve the output under the conditions that each inverter capacity is $3 \mathrm{kVA}$ (with a power factor of 0.8 ) and the output voltage is singlephase $100 \mathrm{~V}, 60 \mathrm{~Hz}$. The specification of wind \& solar energy storage system, battery, the fuel cell is displayed in Table I, II, III \& IV correspondingly. 


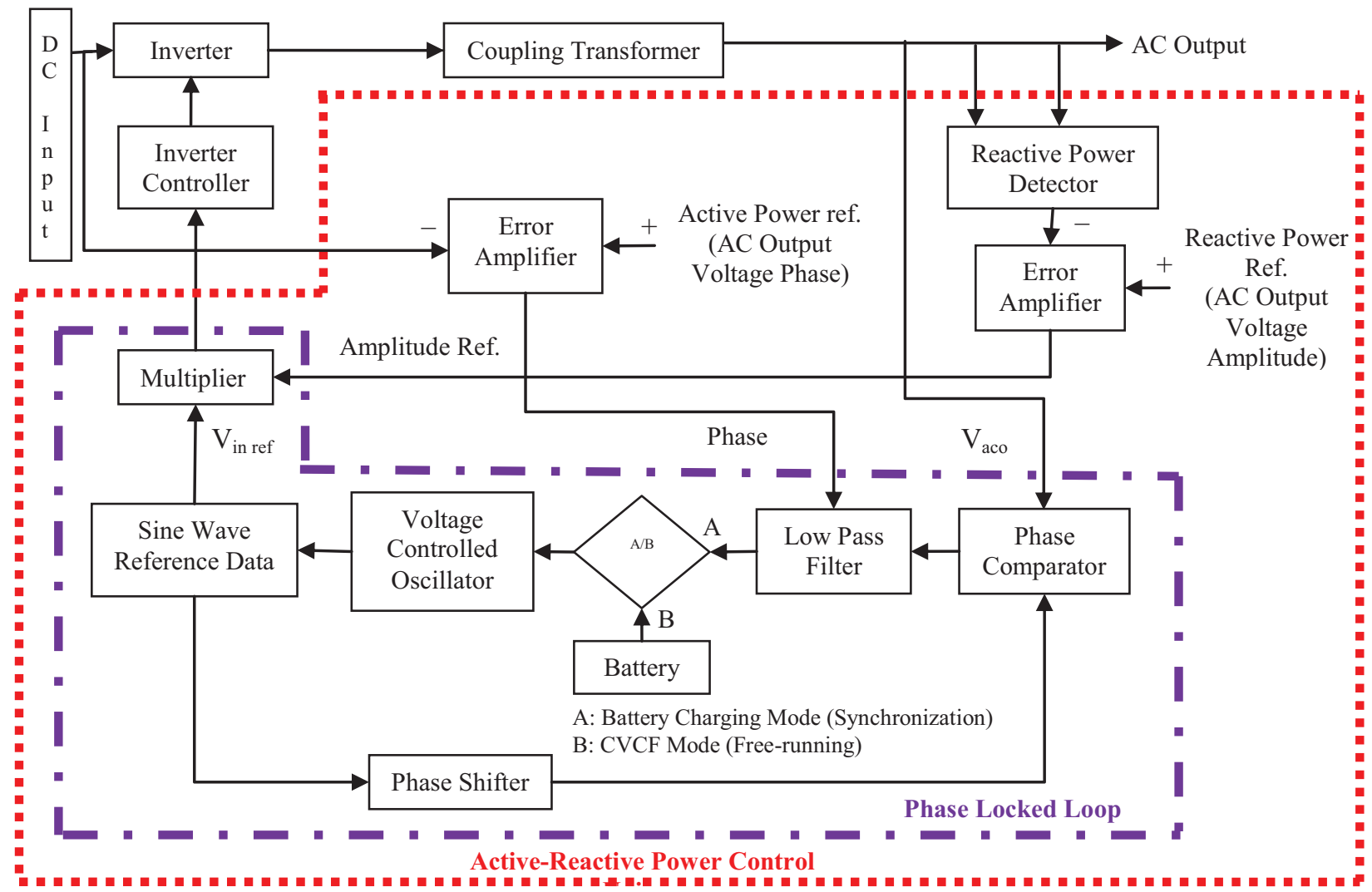

Figure 3. Basic power control block of the inverter section

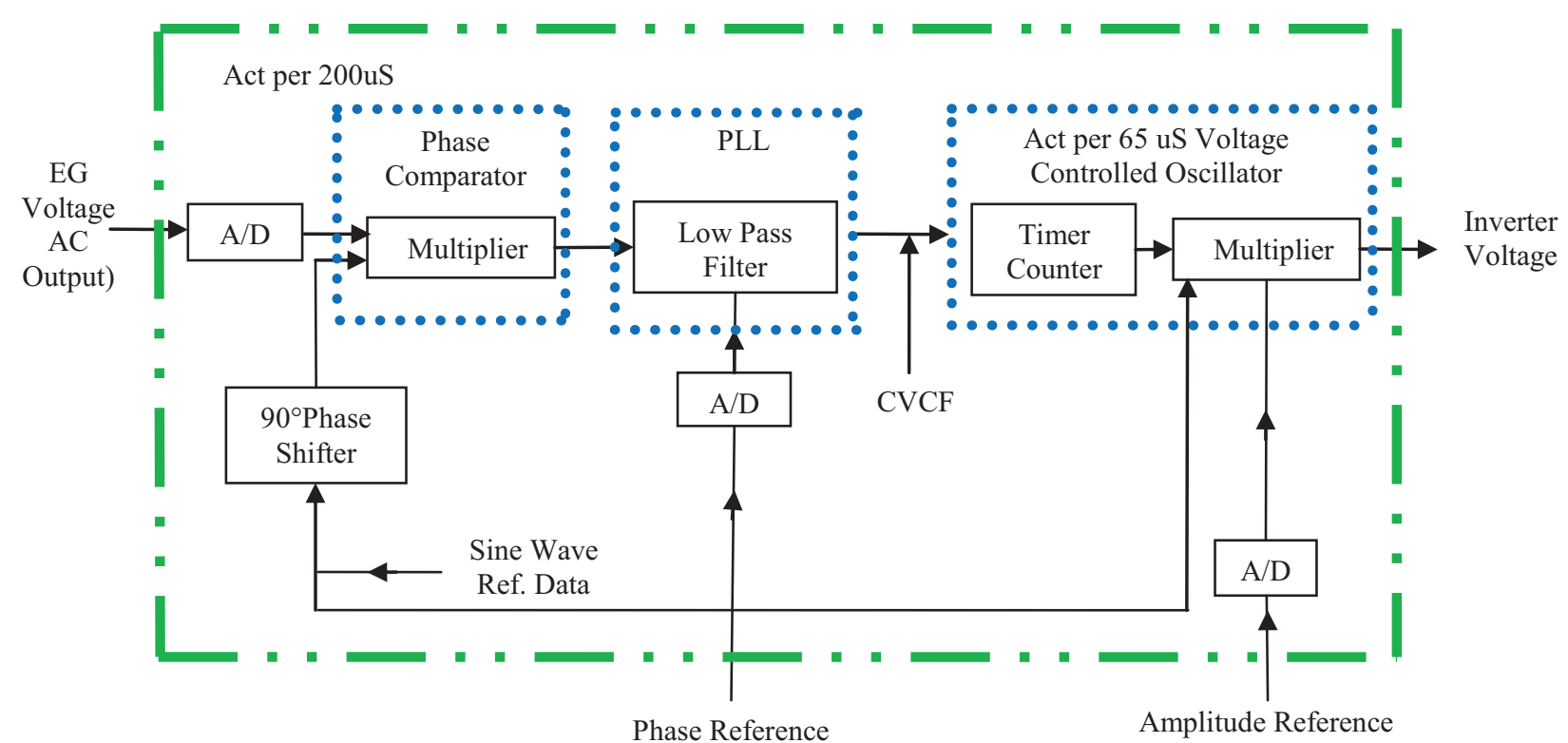

Figure 4. Phase-locked loop control 
TABLE I

SPECIFICATION OF WIND ENERGY PRODUCTION SYSTEM

\begin{tabular}{|l|l|}
\hline Item & Specification \\
\hline Wind Energy & $3.5 \mathrm{~kW}$ \\
\hline Output Capacity & 3 -phase,3-wire AC 100V \\
\hline Output Voltage & $3.5 \mathrm{~kW}$ \\
\hline AC-DC Converter & DC 250V \\
\hline Output Capacity & $3 \mathrm{~kW}$ \\
\hline Output Voltage & $\begin{array}{l}1 \text {-phase, 2-wire, AC100V, 0.8 Power } \\
\text { factor }\end{array}$ \\
\hline DC-AC Inverter &
\end{tabular}

TABLE II.

SPECIFICATION OF THE SOLAR ENERGY PRODUCTION SYSTEM

\begin{tabular}{|l|l|}
\hline Item & Specification \\
\hline Solar Panel & $3.41 \mathrm{~kW}$ \\
\hline Output Capacity & DC $344 \mathrm{~V}$ \\
\hline Open Circuit Voltage & $3 \mathrm{~kW}$ \\
\hline DC-AC Inverter & $\begin{array}{l}\text { 1-phase,2-wire, AC 100V, 0.8 Power } \\
\text { factor }\end{array}$ \\
\hline Output Capacity
\end{tabular}

TABLE III.

SPECIFICATION OF THE STORAGE BATTERY SYSTEM

\begin{tabular}{|l|l|}
\hline Item & Specification \\
\hline Battery Bank Module \\
\hline Rated Voltage & DC 12V \\
\hline Rated Capacity & $24 \mathrm{Ah}$ \\
\hline Battery Bank Unit \\
\hline Rated Voltage & DC $288 \mathrm{~V}$ \\
\hline Rated Charging Voltage & DC $332.1 \mathrm{~V}$ \\
\hline Rated Charging Current & DC 10A \\
\hline Connection & $\begin{array}{l}24 \text { modules connected in series in two } \\
\text { parallel }\end{array}$ \\
\hline DC-AC Bidirectional Inverter \\
\hline Output Capacity & $3 \mathrm{~kW}$ \\
\hline Output Voltage & $\begin{array}{l}\text { 1-phase, 2-wire, AC 100V, 0.8 Power } \\
\text { factor }\end{array}$ \\
\hline
\end{tabular}

TABLE IV.

SPECIFICATION OF THE ENGINE ALTERNATOR

\begin{tabular}{|l|l|}
\hline Item & Specification \\
\hline Output Capacity & $10 \mathrm{kVA}$ \\
\hline Output Voltage & $\begin{array}{l}\text { 1-phase, 2-wire, AC 100V, 0.8 Power } \\
\text { factor }\end{array}$ \\
\hline
\end{tabular}

Assume $V_{s m}$ is defined as the input side voltage and $V_{r}$ as the load side voltage, and the angle of phase difference is $\delta$, each of $P_{s m}, Q_{s m}, P_{r m}$, and $Q_{r m}$ is represented as follows [18], [19]:

$$
\begin{gathered}
P_{s m}=P_{r m}=\frac{V_{s m} V_{r}}{X_{m}} \sin \delta \\
Q_{s m}=\frac{V_{s m}^{2}-V_{s m} V_{r} \cos \delta}{X_{m}} \\
Q_{r m}=\frac{V_{s m} V_{r} \cos \delta-v_{r}^{2}}{X_{m}}
\end{gathered}
$$

Where active power is $P_{s m}$ and reactive power is $Q_{s m}$ at the sending-end active power is $P_{r m}$ and the reactive power is $Q_{r m}$ at the load-side, and the reactance of the interlinked reactor is $X_{m}$.

Here, $m$ indicates the number of power sources operated in parallel. It is attractive to regulate the voltage amplitude variation and the angle of phase variation to be inside the period from $5 \mathrm{~V}$ to $15 \mathrm{~V}$, and from $5 \circ$ to $10^{\circ}$, respectively, based on the behavior of the real-reactive energy control unit as shown in Fig. 5.

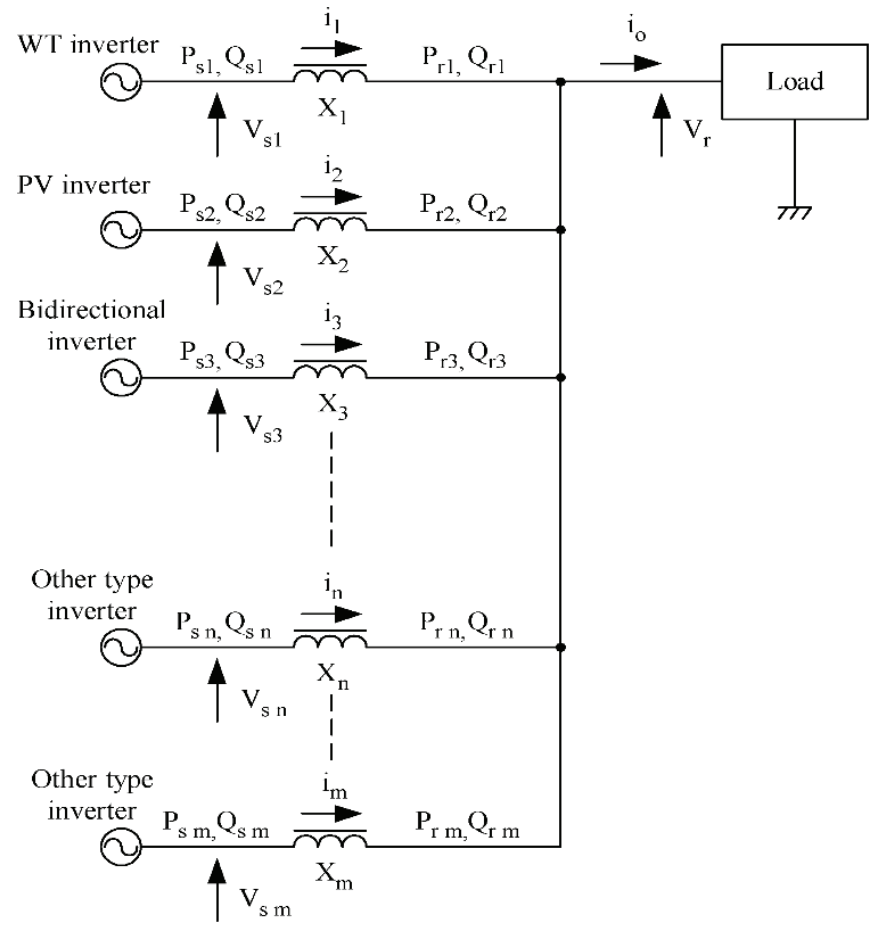

Figure 5. Operating model of parallel inverters. 


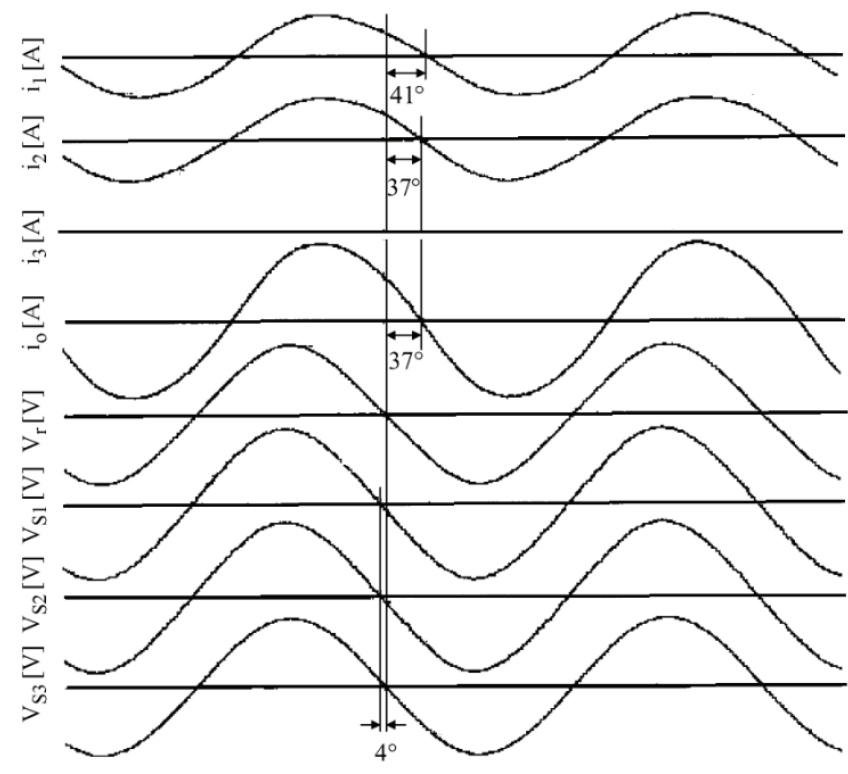

Figure 6. Each inverter current and voltage waveforms.

When $\delta$ is $7.5^{\circ}$ and $V_{r}$ is $100 \mathrm{~V}, V_{s m}$ becomes $109 \mathrm{~V}$ by using (1) and (2). The reactance of the interlinked reactor becomes $1.57 \mathrm{mH}$.

Fig.6. shows each inverter current and voltage waveforms. $50 \%$ of real energy is sent to the load by separate WT and PV inverters. Under this condition reactive energy of the battery bank, two-directional inverters became zero. The capacity of the load is $3 k V A$, and the power factor is 0.8 .

The rating of each lead-acid battery module is $12 \mathrm{~V}, 24 \mathrm{Ah}$. The battery unit consists of 24 battery modules connected in series in two parallel rows. The balanced charging voltage is set as $331.2 \mathrm{~V}$, and the charging current is set at $10 \mathrm{~A}$.

\section{B. Diversion power control}

The real-reactive energy control method is developed for the successful control of diversion power. When either wind power or PV power production becomes better than load, EG stops, and the 2-directional inverter as a grasp is operated underneath the CVCF situation. Then, the remaining portion obtained after removed load from production power (diversion power), is used as a charging power for the battery bank. In the course of battery charging, an advanced technique to prevent battery overcharge is required. Diversion load (e.g., resistive load or radiator), to utilize diversion power, is usually placed in parallel with the battery or AC output.

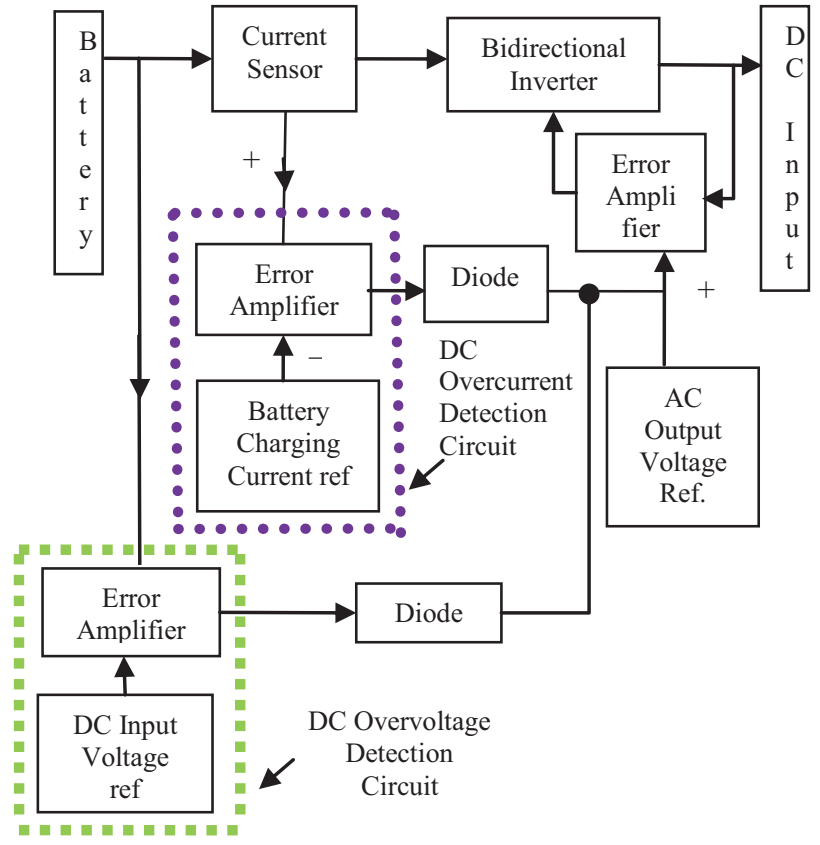

Figure 7. Bidirectional inverter dump power control

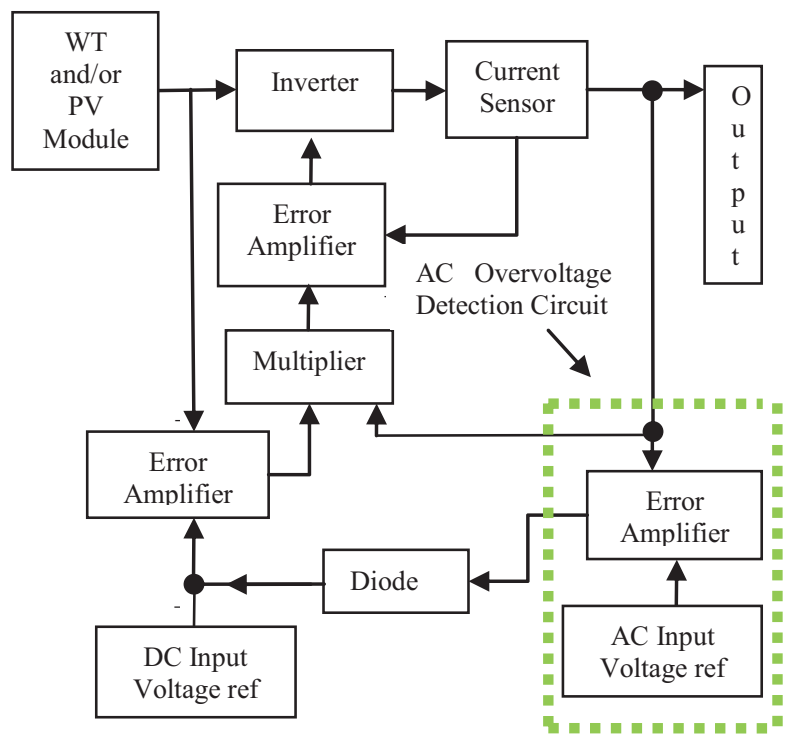

Figure 8. WT and PV inverters dump power control

The diversion power changes continuously, it is challenging to adjust the diversion load by simply input diversion load, because this hinders flexible control of battery charging. To stabilize both the charging current and voltage of the battery bank, the improved matchless advanced dump power control method is factorized by diversion energy guidelines without any diversion load and their difference is shown in Fig. $7 \&$ 8. This method allows for immediate response to diversion energy as well as a decrease in unwanted diversion power control, contributes to more successful use of natural energy. 


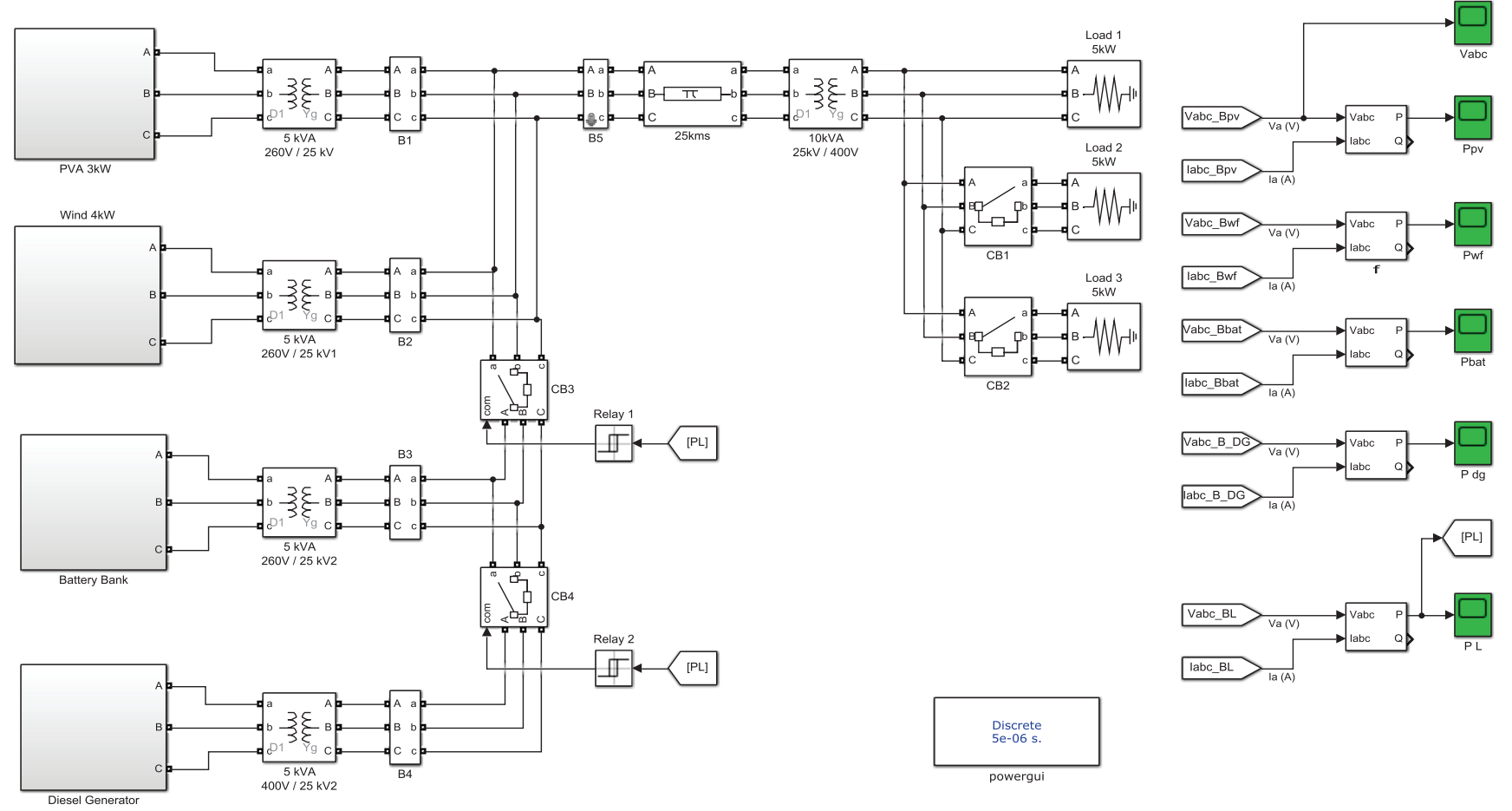

Figure 9. Simulation diagram of the hybrid power system with PVA, wind farm, battery, diesel generator.

\section{Simulation ReSUlts AND DisCUSSIONS}

The simulation diagram of the hybrid power system is shown in Fig.9. The proposed hybrid system consists of four energy sources such as PVA, wind farm, storage battery, and diesel generator. The solar PVA and wind farm are directly connected to the load through a transmission line, whereas the battery and diesel generator is connected to the transmission line through a circuit breaker (CB). For every system, the $5 \mathrm{kVA}$ rating of the transformer is used to step up the voltages. All the above four systems are operated in parallel by synchronizing their phase angles and magnitudes.

The synchronization is done by using the Synchronous Reference Frame (SRF) controller. The SRF controller has been implemented in all four systems to maintain synchronization. In this system total, three loads are introduced. Each load consumes $5 \mathrm{kw}$ power, i.e., the total power consumed by the load is $15 \mathrm{~kW}$. Hence, it is needed to supply the $15 \mathrm{~kW}$ power to the load by synchronizing all the four sources. The results of different energy systems are simulated in a MATLAB environment as shown below.

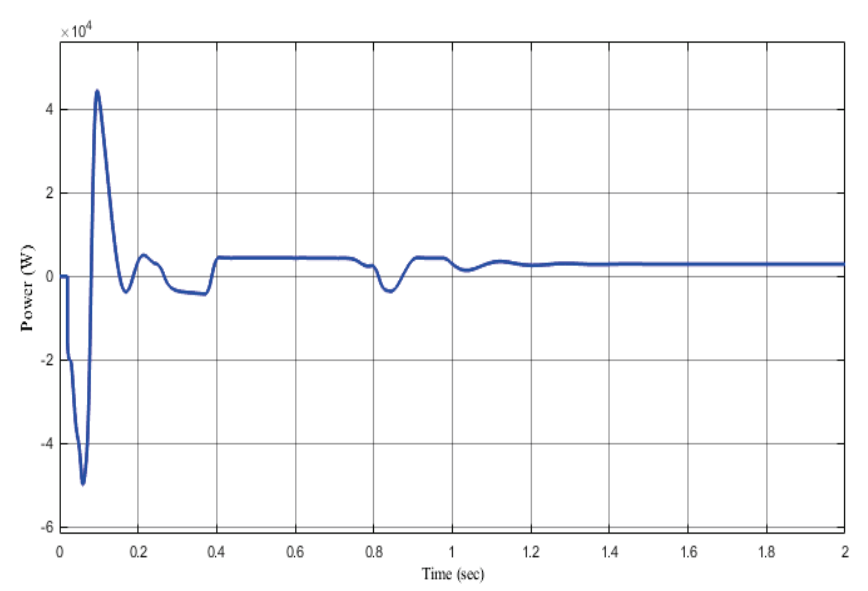

Figure 10. Solar PVA output power.

The PVA generates $3 k W$ power, but the power given to the load is $2.650 \mathrm{~kW}$ only. The $350 \mathrm{~W}$ power is lost due to the conversion and transformation losses in the system. The above graph shows the solar output power, initially, transients are present in the system. Then the system came into a stable state and supply $2.650 \mathrm{~kW}$ to the load as shown in Fig. 10. 


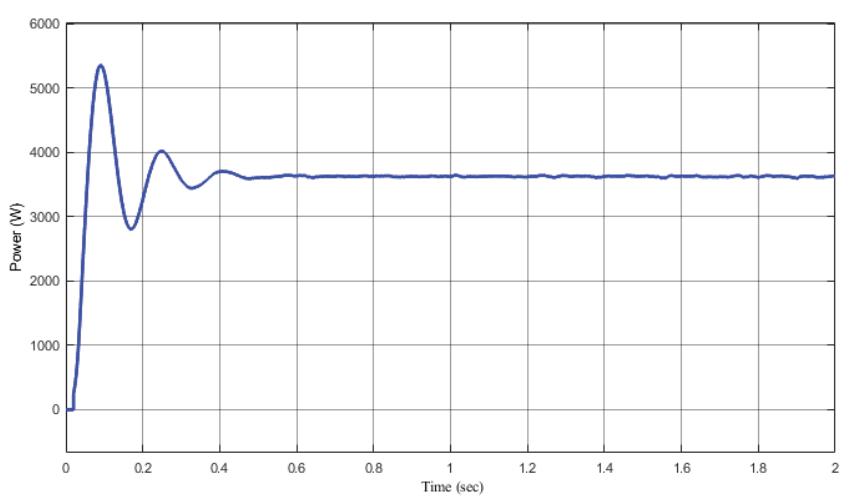

Figure 11. Windfarm output power

The actual power generated by the wind farm is $4 \mathrm{~kW}$, but due to losses the power injected into the load is only $3.30 \mathrm{~kW}$. The remaining $700 \mathrm{~W}$ power is lost due to the rotating parts of the wind turbine. The Permanent Magnet Synchronous Generator (PMSG) is used in the wind energy system. Initially, there are transients in the system, then the system came into a stable position and supplies $3.30 \mathrm{~kW}$ to the load. The simulation result is shown in Fig. 11.

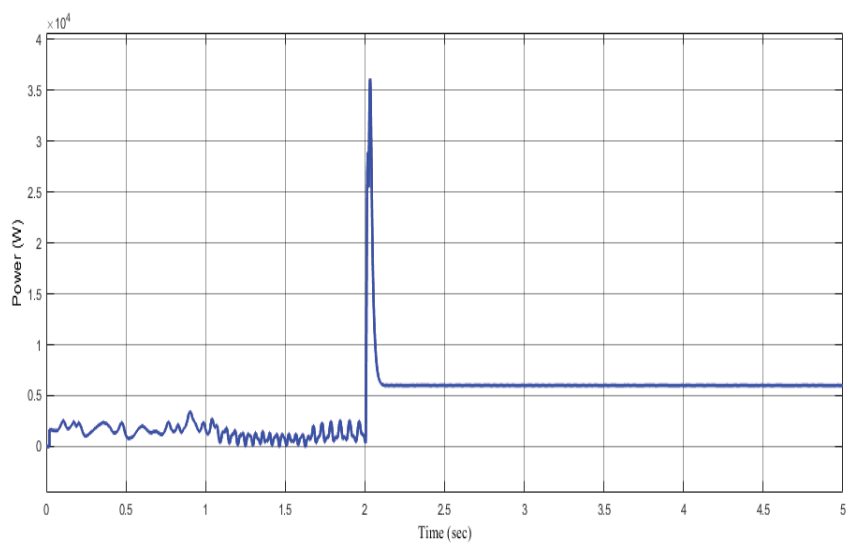

Figure 12. Storage battery output power

The lead-acid battery is used with the rating of $E=450 \mathrm{~V}$ with the capacity of 24 Ampere hours (Ah). There are two states in the battery i.e, charging and discharging state. The Fig.12. shows there is a transient (harmonics) in the starting and the negative part of the graph shows the charging of a battery and the positive part shows the discharging of a battery. If the State of Charge (SoC) is $80 \%$ it indicates the discharging of a battery and $10 \%$ indicates the charging of a battery.

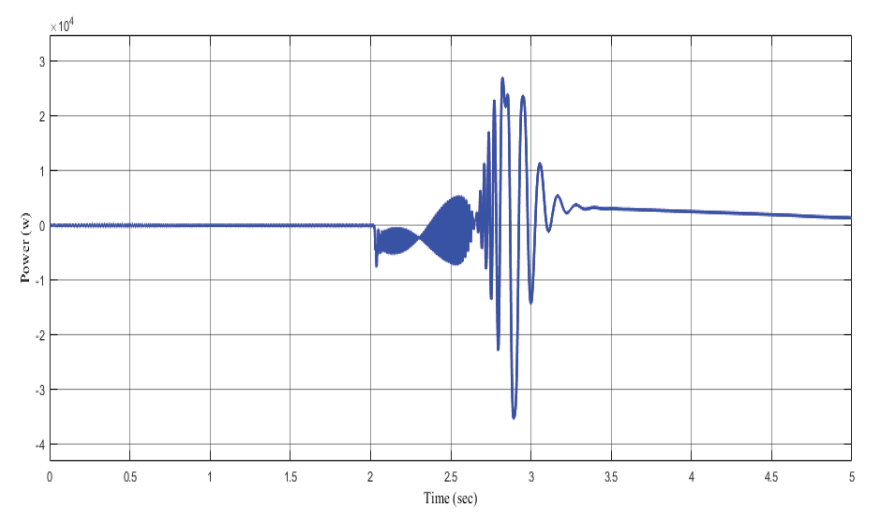

Figure 13. Diesel generator output power

The diesel generator generates only $2 k W$ to the load. It is used as a backup device. Initially, there are transients in the system then it becomes the stable state and supplies power to the load shown in Fig.13. It is a non-renewable energy resource. The cost of fuel is high, so, instead of using diesel, one more renewable energy source i.e, the fuel cell is introduced.

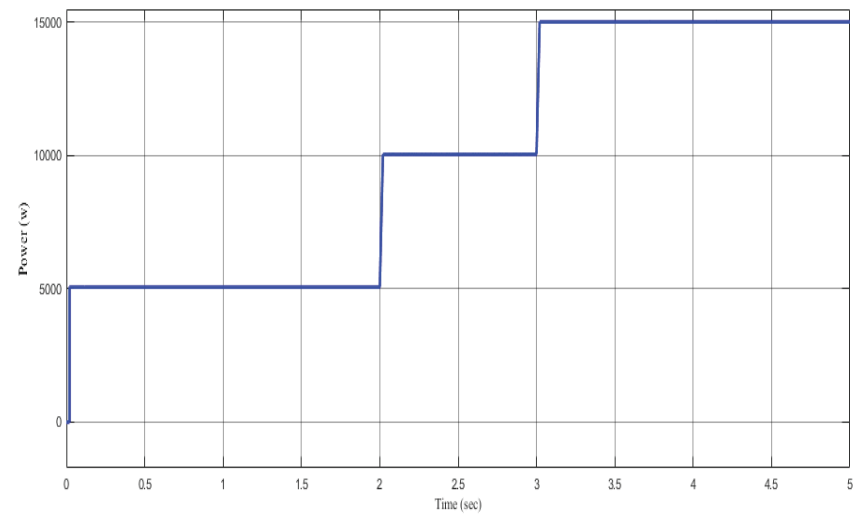

Figure 14. Load output power

In Fig. 14, three loads are added each load consists of $5 \mathrm{~kW}$. Depends upon the load demand the renewable energy sources are activated. If the first load demand is $5 k W$ then PVA and wind farm supplies power to the load. If the second load is added into the system, then the total load demand is $10 \mathrm{~kW}$. Then the power supplied by the wind farm and solar didn't sufficient to meet the load demand. Hence the storage battery supplies the power to the load demand. If the third load is added then the power supplied by these three devices is not sufficient. Hence in this situation, all the four energy sources are activated and supply power to meet the load demand. 

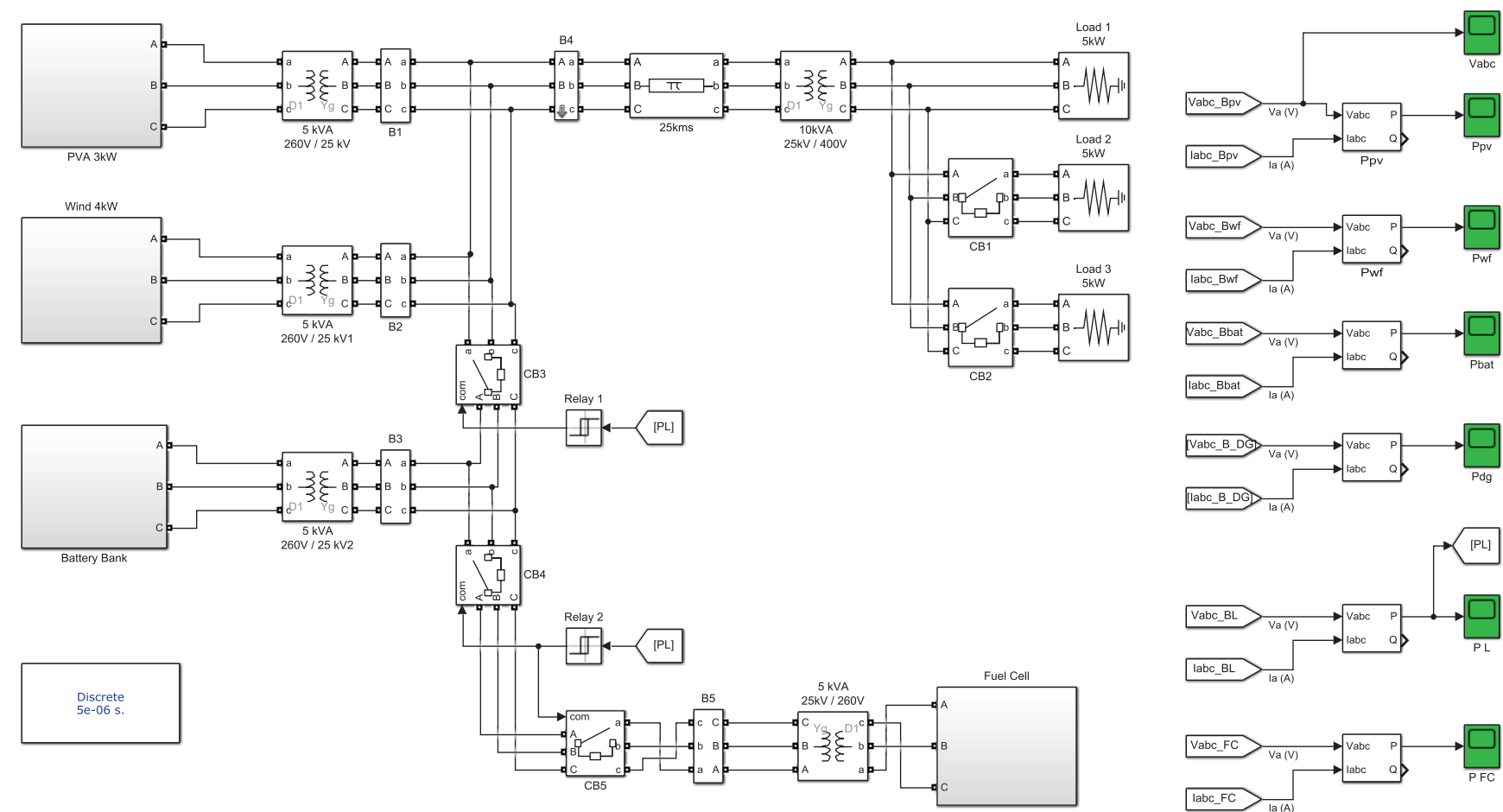

Figure 15. Simulation diagram of hybrid power system with PVA, windfarm, battery \& fuel cell

The Fig.15. shows the simulation diagram of four energy sources, but all these are renewable energy sources only. But in the simulation diagram Fig.9. there is one diesel generator (non-renewable energy source) is connected. Here diesel generator is detached and fuel cells are introduced to reduce the cost so that the system efficiency is improved.

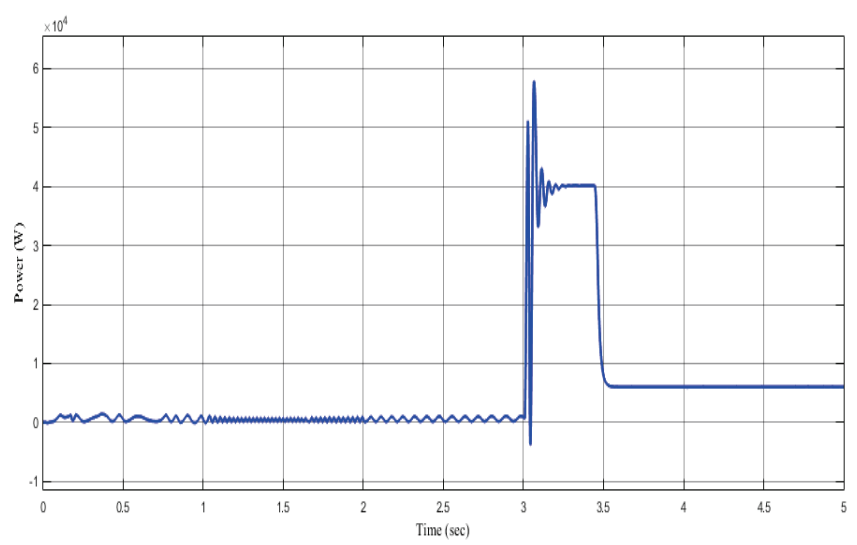

Figure 16. Fuel cell output power

The fuel cell generates $6 k W$ this power is supplied to the load when PVA, wind farm, and the storage battery is not able to fulfill the load demand. The effective use of fuel cells is also presented in the paper for optimal operation.

\section{Conclusions}

This paper is equipped with a self-power composite electricity production system, comprised of PLL and diversion energy control. The diversion energy control allows for the arrangement of a return path in this system, there is no need for a devoted ultra-speed line to deliver battery storage voltage and current information. If the energy line is used as a medium for the transfer of data, the line voltage magnitude is used as the transfer of data. So, there is no usage of a fiber optic communication line or the energy line transporter system via which harmonic signals are applied to the energy line. Moreover, neither the diversion load nor diversion load control device is required. Under the proposed diversion energy control, management of output is done without the battery fully charging, and effective use of excess energy is made possible. This furnishes to the extension of battery life and comprehension of a less-price system. The system, via the AC system interlinked, has allowed the stretchy expansion of the system in the future. Energy sources together with EG have interconnected flexibly any location with the same energy line, and the energy quality constant is maintained by controlling the phase and magnitude of the AC output voltage. It is estimated that this composite system with natural energy makes use of a variety of power control techniques, is validated. With the above-considered system without the connection from the main grid, i.e., in the offgrid, the battery and $6 \mathrm{~kW}$ fuel cells can improve the stability of the system. In the same off-grid time, the $\mathrm{SoC}$ is $80 \%$, which means that the battery and fuel cell is fully utilized thus maintaining efficiency. The system will also help other developing countries in context protection through an appeal on remote islands with no dependence on marketable energy systems. 


\section{REFERENCES}

[1] M.Uzunoglu, \& M.S.Alam, "Dynamic modeling, design, and simulation of a combined PEM fuel cell and ultracapacitor system for stand-alone residential applications," IEEE Transactions on Energy Conversion, vol.21, no.3, pp.767775,2006

[2] N.A.Ahmed, M.Miyatake, \& A.K.Al-Othman, "Power fluctuations suppression of stand-alone hybrid generation combining solar photovoltaic/wind turbine and fuel cell systems," Energy Conversion and Management, vol.49, no.10, pp.2711-2719, 2008.

[3] S.K. Kim, J.H. Jeon, C.H. Cho, J.B. Ahn, and S.H. Kwon, "Dynamic modeling and control of a grid-connected hybrid generation system with versatile power transfer," IEEE Trans. Ind. Electron., vol. 55, no. 4, pp. 1677-1688, Apr. 2008.

[4] W.Li, G.Joos, and J.Belanger, "Real-time simulation of a wind turbine generator coupled with a battery super capacitor energy storage system," IEEE Trans. Ind. Electron., vol. 57, no. 4, pp. 1137-1145, Apr. 2010.

[5] K.Karakoulidis, K.Mavridis, D.V.Bandekas, P.Adoniadis, "Techno-economic analysis of a stand-alone hybrid photovoltaic-diesel-battery-fuel cell power system," Renewable Energy, vol.36, no.8, pp.2238-2244, 2011.

[6] A.I.Bratcu, I.Munteau, S.Bacha, D.Picault, and B. Raison, "Cascaded dc-dc converter photovoltaic systems: Power optimization issues," IEEE Trans. Ind. Electron., vol. 58, no. 2, pp. 403-411, Feb. 2011.

[7] E.Dursun, \& O.Kilic, "Comparative evaluation of different power management strategies of a stand-alone PV/Wind/PEMFC hybrid power system," International Journal of Electrical Power \& Energy Systems, vol.34, no.1, pp.81-89, 2012.

[8] M.Rezkallah, A.Chandra, D.R.Rousse, H.Ibrahim, "Control of small-scale wind/diesel/battery hybrid standalone power generation system based on fixed speed generators for remote areas," In IECON 2016-42nd Annual Conference of the IEEE Industrial Electronics Society, vol.42, pp.4060-4065, 2016.

[9] V.Raviprabakaran, \& R.C.Subramanian, "Enhanced ant colony optimization to solve the optimal power flow with ecological emission,". International Journal of System Assurance Engineering and Management, vol.9, no. 1, pp.58$65,2018$.

[10] S.Das, \& A.K.Akella, "Power flow control of PV-windbattery hybrid renewable energy systems for stand-alone application," International Journal of Renewable Energy Research (IJRER), vol.8, no.1, pp.36-43, 2018.

[11] R.Vijay, "Quorum sensing driven bacterial swarm optimization to solve practical dynamic power ecological emission economic dispatch," International Journal of Computational Methods, vol.15, no. 03,pp. 1850089-24,2018.

[12] A.F.Bendary, \& M.M.Ismail, "Battery charge management for hybrid PV/wind/fuel cell with storage battery," Energy Procedia, vol.162, pp.107-116, 2019.

[13] A.Amar Bensaber, M.Benghanem, A.Guerouad, \& M.Amar Bensaber, "Power flow control and management of a Hybrid Power System," Przegląd Elektrotechniczny, vol. 9, no.1, pp.189-190, 2019.

[14] A.Shaqour, H.Farzaneh, Y.Yoshida, \& T.Hinokuma, "Power control and simulation of a building integrated stand-alone hybrid PV-wind-battery system," in Kasuga City, Japan. Energy Reports, vol.6, pp.1528-1544, 2020.

[15] V.Raviprabakaran, "Optimal and stable operation of microgrid using enriched biogeography based optimization algorithm," Journal of Electrical Engineering, vol.17, no. 4, pp.1-11, 2018.
[16] C.Ghenai, T.Salameh, \& A.Merabet, "Technico-economic analysis of off grid solar PV/Fuel cell energy system for residential community in desert region," International Journal of Hydrogen Energy, vol.45, no.20, pp.11460-11470, 2020. 